Article

\title{
Combined Pretreatment by Ultrasound and Struvite Precipitation of Raw Substrates: A Strategy to Overcome C/N Ratio Unbalance in Nitrogen-Rich Anaerobic Co-Digestion Systems
}

\author{
Renata D'arc Coura 1,* , Ana Cristina Rodrigues ${ }^{2,3}$, Joaquim Mamede Alonso ${ }^{2,4}$, Ana Isabel Ferraz ${ }^{2,3}$, \\ Luis Miguel Brito ${ }^{5}$, João Carlos de Castro Abrantes ${ }^{2}$ and António Guerreiro Brito ${ }^{1}$ \\ Citation: Coura, R.D.; Rodrigues, \\ A.C.; Alonso, J.M.; Ferraz, A.I.; Brito, \\ 1 LEAF - Linking Landscape, Environment, Agriculture and Food, Instituto Superior de Agronomia, \\ Universidade de Lisboa, 1349-017 Lisboa, Portugal; agbrito@isa.ulisboa.pt \\ 2 ProMetheus-Research Unit in Materials, Energy and Environment for Sustainability, Instituto Politécnico de \\ Viana do Castelo, 4900-347 Viana do Castelo, Portugal; acrodrigues@esa.ipvc.pt (A.C.R.); \\ malonso@esa.ipvc.pt (J.M.A.); aferraz@esa.ipvc.pt (A.I.F.); jabrantes@estg.ipvc.pt (J.C.d.C.A.) \\ 3 CEB-Centre of Biological Engineering, Universidade do Minho, Campus de Gualtar, \\ 4710-057 Braga, Portugal \\ 4 CIBIO-InBIO-Research Centre in Biodiversity and Genetic Resources, Universidade do Porto, Campus de \\ Vairão Rua Padre Armando Quintas, 7, 4485-661 Vairão, Portugal \\ 5 CIMO-Mountain Research Center, Escola Superior Agrária, Instituto Politécnico de Viana do Castelo, \\ 4990-706 Ponte de Lima, Portugal; miguelbrito@esa.ipvc.pt \\ * Correspondence: rcoura@esa.ipvc.pt or renatacoura@isa.ulisboa.pt
} L.M.; Abrantes, J.C.d.C.; Brito, A.G. Combined Pretreatment by

Ultrasound and Struvite

Precipitation of Raw Substrates: A Strategy to Overcome C/N Ratio Unbalance in Nitrogen-Rich Anaerobic Co-Digestion Systems. Sustainability 2021, 13, 2175. https:// doi.org/10.3390/su13042175

Academic Editor: Andreas N. Angelakis

Received: 31 December 2020

Accepted: 14 February 2021

Published: 18 February 2021

Publisher's Note: MDPI stays neutral with regard to jurisdictional claims in published maps and institutional affiliations.

Copyright: () 2021 by the author. Licensee MDPI, Basel, Switzerland. This article is an open access article distributed under the terms and conditions of the Creative Commons Attribution (CC BY) license (http://creativecommons.org/licenses/by/4.0/).

\begin{abstract}
The present study aimed to optimize the struvite chemical precipitation process in nitrogenrich anaerobic co-digestion systems. Struvite precipitation experiments were carried out using a mixture of cattle slurry liquid fraction and sewage sludge, with and without ultrasound pretreatment. Marine salt or $\mathrm{MgCl}_{2}$ were used as magnesium source in $\mathrm{NH}_{4}{ }^{+}: \mathrm{Mg}^{2+}$ stoichiometric proportions of 1:1.5 and 1:3. Under the tested conditions, ammonium nitrogen and orthophosphate were removed from the mixed liquor with a maximum observed efficiency of $43 \%$ and $92 \%$, respectively, when the ultrasound treatment was applied prior to struvite precipitation, using $\mathrm{MgCl}_{2}$ as source of magnesium $\left(\mathrm{NH}_{4}^{+}: \mathrm{Mg}^{2+}\right.$ of 1:3). The operating time was $40 \mathrm{~min}$. Different pretreatments were tested prior to the biomethanization experiments, struvite precipitation, ultrasound, or a combination of both pretreatments. The application of ultrasound (with an energy input of $218 \mathrm{~kJ} \mathrm{~L}^{-1}$ ) and struvite precipitation $\left(\mathrm{NH}_{4}{ }^{+}: \mathrm{Mg}^{2+}\right.$ of $\left.1: 3\right)$ increased the methane content in the biogas by $82 \%$ and reduced hydraulic retention time by $28 \%$, when compared to the anaerobic co-digestion assays without pretreatment. The hydrolytic pretreatment increased the bioavailability of nitrogen by $5 \%$, thus enhancing the removal efficiency of ammonium nitrogen by $20 \%$. Consequently, an increase in the carbon to nitrogen ratio was observed, favoring the methanogenesis process.
\end{abstract}

Keywords: ultrasound pretreatment; struvite precipitation; nutrient recovery; circular economy; anaerobic (co)digestion

\section{Introduction}

The most recent trend in wastewater treatment processes is to foster bottom-up synergies in order to advance resource recovery and move towards a circular economy. In this regard, wastewaters produced at dairy farms are accessible sources for nutrient and bioenergy recovery. Removal of nitrogen $(\mathrm{N})$ and phosphorous $(\mathrm{P})$ from wastewaters is becoming an increasing challenge for operators as regulatory authorities tighten discharge standards to avoid eutrophication problems in receiving water bodies. Another 
environmental burden concerns the excess of sewage sludge (SwS) from wastewater treatment plants (WWTP). Anaerobic digestion (AD) processes are currently used to produce biogas from sewage sludge with the aim of recovering heat and electricity. However, anaerobic digestion units are often operated at sub-optimal performance due to a variety of factors, among which the excess of nitrogen and the low biodegradability of substrates are commonly referred [1,2].

The anaerobic digestion inhibition by excess of nitrogen can be caused by the accumulation of ammonia $\left(\mathrm{NH}_{3}\right)$ and ammonium ion $\left(\mathrm{NH}_{4}^{+}\right)$in the system. The total ammonium nitrogen (TAN) concentrations in the range of $1500-3000 \mathrm{mg} \mathrm{L}^{-1}$ may cause partial inhibition and complete inhibition was observed at concentrations above $3000 \mathrm{mg} \mathrm{L}^{-1}[1,3-$ 5]. According to Astals et al. (2018) [6], the methanogenesis was partially inhibited at a free ammonia nitrogen (FAN) concentration below $15 \mathrm{mg} \mathrm{L}^{-1}$ and totally inhibited at and above $130 \mathrm{mg} \mathrm{L}^{-1}$. Other studies reported potential inhibition in a variety of FAN concentrations, ranging from 0.05 to $1.4 \mathrm{~g} \mathrm{~L}^{-1}[5,7]$.

The anaerobic co-digestion (AcoD) of different substrates may be used as a strategy to overcome the carbon to nitrogen ratio $(\mathrm{C} / \mathrm{N})$ unbalance phenomenon $[8,9]$ and maximize methane production in energy recovery systems. In a circular economy approach, nutrient recovery is also a key factor and both sewage sludge and dairy farm wastewaters are perceived as nutrient-rich sources, with an interesting potential for nitrogen, phosphorus, calcium, and potassium recovery and application in agriculture [10].

One of the techniques used to recover nitrogen and phosphorus from wastewater is the precipitation of struvite (magnesium ammonium phosphate-MAP, $\mathrm{MgNH}_{4} \mathrm{PO}_{4} 6 \mathrm{H}_{2} \mathrm{O}$ ). The process can be affected by the chemical composition of the wastewater, temperature and $\mathrm{pH}$ [11]. Many authors reported the use of different sources of magnesium such as $\mathrm{Mg}(\mathrm{OH})_{2}$ [12], $\mathrm{MgCl}_{2}$ [13], $\mathrm{MgSO}_{4}$ [14], and $\mathrm{MgO}$ [15]. As a $\mathrm{pH}$ dependent process, the wider $\mathrm{pH}$ range reported is from 7 to 11 [14,16]. Yoshino et al. (2003) [14] reached high nutrient removal efficiencies under the conditions $\mathrm{pH}$ of 8.5.

In some studies, the solids present in the waste or wastewater are not separated from the liquid prior to struvite precipitation. So, the resulting settled material includes organic matter and other constituents contained in the raw substrates and, therefore, does not qualify as a pure struvite, but as struvite containing sludge [17].

The low biodegradability of substrates may also limit biogas production rate. However, substrate pretreatment with ultrasound may induce solubilization of organic compounds, thus increasing wastewater biodegradability. The ultrasonication by cavitation consists of disrupting the microbial cells by the growth and collapse of gas-bubbles causing an extraction of the intracellular material [18]. Pretreatment of substrates using ultrasound can have several beneficial effects for AD processes. These benefits include i) reducing the particle size [18], ii) increasing the rate of hydrolysis [19], and iii) shortening hydraulic retention time [20]. An increase in the solubilization rate of extracellular and intracellular substances, further benefits the struvite precipitation by increasing the bioavailability of $\mathrm{NH}_{4}^{+}$and $\mathrm{PO}_{4}{ }^{3-}$ ions [21,22].

Struvite precipitation has been mostly applied as an anaerobic digestion post-treatment process. Indeed, struvite precipitation not only allows the removal of $\mathrm{NH}_{4}{ }^{+}$and $\mathrm{PO}_{4}{ }^{3-}$ from anaerobically digested wastewater [13] in order to meet the legal requirements for effluent discharge, but it also presents the opportunity to recover and reuse these macronutrients as a valuable fertilizer [23]. However, the present research follows an alternative approach, aiming at advancing the knowledge on controlled struvite precipitation for application prior to the biomethanization process as a strategy to overcome potential inhibition by ammonium nitrogen. In that regard, the present study is focused on assessing the effects of: (i) two different sources of magnesium (marine salt and $\mathrm{MgCl}_{2}$ ), (ii) two different stoichiometric $\mathrm{NH}_{4}^{+}: \mathrm{Mg}^{2+}$ ratios (1:1.5 and 1:3); (iii) ultrasound pretreatment prior to struvite precipitation; and (iv) combined pretreatment of ultrasound and struvite precipitation prior to the biomethanation process in anaerobic sequencing batch reactor (ASBR). 


\section{Materials and Methods}

Two main sets of experiments were performed, the first one aiming at optimizing struvite precipitation in a mixture of cattle slurry liquid fraction (CSLF) and sewage sludge, and the other one comprising biomethanation assays with and without pretreatment.

\subsection{Struvite Precipitation Optimization Batch Assays}

In order to identify the optimal conditions for struvite precipitation in a mixture of cattle slurry liquid fraction and sewage sludge, five assays were performed under different operational conditions, as described in Table 1.

Table 1. Assays description.

\begin{tabular}{|c|c|}
\hline & Assays Description \\
\hline Control & - \\
\hline MS & $\begin{array}{l}\text { marine salt as source of magnesium using a NH} 4^{+}: \mathrm{Mg}^{2+} \text { stoichiometric pro- } \\
\text { portion of } 1: 1.5\end{array}$ \\
\hline MC1 & $\begin{array}{c}\mathrm{MgCl}_{2} \text { as source of magnesium using a } \mathrm{NH}_{4}^{+}: \mathrm{Mg}^{2+} \text { stoichiometric propor- } \\
\text { tion of } 1: 1.5\end{array}$ \\
\hline MC2 & $\begin{array}{l}\mathrm{MgCl}_{2} \text { as source of magnesium using a } \mathrm{NH}_{4}^{+}: \mathrm{Mg}^{2+} \text { stoichiometric propor- } \\
\text { tion of } 1: 3\end{array}$ \\
\hline $\mathrm{MC} 2 \mathrm{U}$ & $\begin{array}{l}\text { ultrasound pretreatment with an energy input (EI) of } 218 \mathrm{~kJ} \mathrm{~L}^{-1} \text { followed } \\
\text { by struvite precipitation using } \mathrm{MgCl}_{2} \text { as magnesium source and a } \\
\qquad \mathrm{NH}_{4}{ }^{+}: \mathrm{Mg}^{2+} \text { stoichiometric proportion of } 1: 3\end{array}$ \\
\hline
\end{tabular}

\subsubsection{Substrates Pretreatment with Ultrasound}

The ultrasound pretreatment was conducted using an ultrasonic processor (SONOREX Super 10P Bandelin) operating at the nominal power of $90.8 \mathrm{~W}$, low-frequency of $35 \mathrm{kHz}$ and temperature of $25^{\circ} \mathrm{C}$. A $500 \mathrm{~mL}$ sample of the mixture of cattle slurry liquid fraction from a dairy farm and sewage sludge from an urban wastewater treatment plant (1:1, in volume) was sonicated for 20 min resulting in an energy input of $218.4 \mathrm{~kJ} \mathrm{~L}^{-1}$ and specific energy (SE) of 10,180 $\mathrm{kJ} \mathrm{kgTS}^{-1}$.

The energy input and specific energy applied were calculated by Equations (1) and (2), respectively, considering that $\mathrm{P}$ is the power in $\mathrm{kWatt}(\mathrm{kW}), \mathrm{t}$ is the treatment time in seconds (s), V is the volume in liters (L) of the mixture of substrates treated and TS ( $\mathrm{kg}$ $\mathrm{L}^{-1}$ ) the total solid content. The operating conditions for the ultrasound pretreatment were selected based on the studies performed by Ruiz-Hermando et al. (2014) [18] and Ometto et al. (2014) [24].

$$
\begin{gathered}
E I\left(\mathrm{~kJ} \mathrm{~L}^{-1}\right)=(P x t) /(V) \\
S E\left(\mathrm{~kJ} \mathrm{~kg}^{-1}\right)=(P x t) /(V x T S)
\end{gathered}
$$

The ultrasound treatment was applied prior to struvite precipitation process, in order to assess its effect on the crystallization process and, further, on biomethanation.

\subsubsection{Struvite Chemical Precipitation}

The struvite precipitation assays were carried out in batch reactors with a working volume of $300 \mathrm{~mL}$ and a mixture of cattle slurry liquid fraction and sewage sludge from an urban wastewater treatment plant (1:1, in volume). The initial $\mathrm{pH}$ was adjusted to 8.5 by dropwise addition of $\mathrm{NaOH}(1 \mathrm{M})$ and then, one of the sources of magnesium was added, as described in Table 1 . The batch reactors were placed in an orbital incubator, at $150 \mathrm{rpm}$ and $35^{\circ} \mathrm{C}$. The experiments were performed with a reaction period of $1 \mathrm{~h}$. Every 20 or $30 \mathrm{~min}$, measurements of $\mathrm{pH}$ (Orion benchtop $\mathrm{pH}$ meter) were performed and the 
$\mathrm{pH}$ was adjusted to 8.5, when necessary. After the reaction period, the solution was allowed to settle for $30 \mathrm{~min}$ and the precipitate was sampled.

\subsubsection{Statistical Analysis}

One-way analysis of variance (ANOVA) was used to assess significant differences between process parameters, in order to assess significant differences between treatments. The significant differences in all comparisons were set at $p<0.05$. SPSS statistics software, in version 22 (SPSS Inc., Chicago, IL, USA) was used for data analyses.

\subsection{Biomethanation Assays}

\subsubsection{Substrates and Inoculum}

The liquid fraction of cattle slurry was collected at the dairy farm of Professional School of Agriculture and Rural Development of Ponte de Lima (Portugal). The sewage sludge was collected from the secondary settling tank of an urban wastewater treatment plant located in Tougues, Portugal. The inoculum used in the present study was collected from the anaerobic digester of the same WWTP.

\subsubsection{Ultrasound Pretreatment}

Ultrasound pretreatment was applied to the mixture of substrates (1:1, in volume), aiming to increase the biodegradability of the mixture and thus, improve the efficiency of the process in terms of methane production.

The ultrasound pretreatment was carried out with an ultrasonic processor (SONOREX Super 10P Bandelin) operating at the nominal power of $90.8 \mathrm{~W}$ and low frequency of $35 \mathrm{kHz}$. Two different treatment times were tested, $20 \mathrm{~min}$ (ASBR2) and $10 \mathrm{~min}$ (ASBR3), resulting in an energy input of $218 \mathrm{~kJ} \mathrm{~L}^{-1}$ and $109 \mathrm{~kJ} \mathrm{~L}^{-1}$, respectively (Equation (1)).

The ultrasound treatment was applied to the mixture of substrates, prior to inoculation and start-up of the anaerobic digester operation, corresponding to a specific energy of 8180 $\mathrm{kJ} \mathrm{kgTS}^{-1}$ and $4270 \mathrm{~kJ} \mathrm{kgTS}^{-1}$, in reactors ASBR2 and ASBR3, respectively (Equation (2)).

\subsubsection{Struvite Precipitation}

Struvite precipitation was induced through the addition of $\mathrm{MgCl}_{2}$ to the mixture of substrates (1:1, in volume) previously treated with ultrasound. The initial $\mathrm{pH}$ was adjusted to 8.5 by dropwise addition of $\mathrm{NaOH}(1 \mathrm{M})$ and then $\mathrm{MgCl}_{2}$ solution $\left(157 \mathrm{~g} \mathrm{~L}^{-1}\right)$ was added in order to achieve the stoichiometric ratio of $\mathrm{NH}_{4}{ }^{+}: \mathrm{Mg}^{2+}$ of 1:3, which led to higher nutrient removal efficiencies in the struvite precipitation assays, as described in Section 3.1.1. The struvite precipitation pretreatment was applied during $1 \mathrm{~h}$, under mesophilic conditions $\left(35^{\circ} \mathrm{C}\right)$. Every $20 \mathrm{~min}$, measurements of $\mathrm{pH}$ (Orion benchtop $\mathrm{pH}$ meter) were performed and adjusted to 8.5, when necessary. Finally, the mixture was allowed to settle.

After the struvite precipitation pretreatment, the entire mixture was inoculated for subsequent anaerobic digestion. The goal was to assess the effect of the use of a combined pretreatment (ultrasound and struvite precipitation) on methane production, in a nitrogen rich system.

\subsubsection{Reactor Start-Up and Experimental Procedure}

Anaerobic (co-)digestion assays, with and without pretreatment (ASBR1, ASBR2, and ASBR3), as described in Table 2, were carried out under mesophilic conditions $\left(35^{\circ} \mathrm{C}\right)$ in anaerobic sequencing batch reactors, mechanically stirred, with a total volume of $8 \mathrm{~L}$ and a working volume of $5.5 \mathrm{~L}$. All the reactors had a water jacket and the temperature was maintained at $35^{\circ} \mathrm{C}$ using a thermostatic bath and a water recirculation system. The gas analyzer (Bluesens BACVis software version 7.6.2.1), connected to the reactor, registered the methane content in the biogas.

Three different reactors were operated under the conditions described in Table 2. 
Table 2. Anaerobic co-digestion assays and pretreatment conditions.

\begin{tabular}{cr}
\hline Reactor & Pretreatment Conditions \\
\hline ASBR1 & ACoD without pretreatment of substrates \\
ASBR2 & ACoD with ultrasound and struvite pretreatment: En- \\
& ergy Input of $218 \mathrm{~kJ} \mathrm{~L}^{-1}$ and $\mathrm{NH}_{4}^{+}: \mathrm{Mg}^{2+}$ of $\left.1: 3\right)$ \\
ACBR3 & $\begin{array}{c}\text { ACoD with ultrasound and struvite pretreatment: En- } \\
\left.\text { ergy Input of } 109 \mathrm{~kJ} \mathrm{~L}^{-1} \text { and } \mathrm{NH}_{4}^{+}: \mathrm{Mg}^{2+} \text { of } 1: 3\right)\end{array}$ \\
\hline
\end{tabular}

The experiment ASBR1 corresponds to the anaerobic co-digestion of SwS and CSLF without pretreatment (control). In experiments ASBR2 and ASBR3 a combination of both pretreatments, ultrasound, and chemical precipitation of struvite, was applied. The assay ASBR3 was performed under the same operational conditions as in assay ASBR2, except for the energy input in ultrasound treatment, which was $109 \mathrm{~kJ} \mathrm{~L}^{-1}$ (SE of $4270 \mathrm{~kJ} \mathrm{kgTS}^{-1}$ ), half of the one applied to reactor ASBR2, $218 \mathrm{~kJ} \mathrm{~L}^{-1}$ (SE of $8180 \mathrm{~kJ} \mathrm{kgTS-1).}$

After the pretreatment, the reactors were inoculated and the gas analyzer system was connected. No nutrient addition or $\mathrm{pH}$ correction were performed during the anaerobic digestion process.

\subsection{Analytical Procedure}

All the analytical procedures followed the guidelines described in APHA (1992) [25] and the parameters analysed were total COD (tCOD), soluble COD (sCOD), total solids (TS), volatile solids (VS), Total Kjeldahl Nitrogen (TKN), total ammonium nitrogen (TAN), orthophosphate ( $\left.\mathrm{PO}_{4}{ }^{3}-\mathrm{P}\right)$ and $\mathrm{pH}$. The total organic carbon (TOC) was determined by the ratio between the organic matter (OM) content, in terms of VS, and the constant 1.8 $[26,27]$. Free ammonia $(F A N)$ was calculated based on TAN concentration, according to Equation (3) [28]:

$$
F A N=T A N\left(\frac{10^{-p H}}{10^{-\left(0.09018+\frac{2729.92}{T}\right)}}\right)^{-1}
$$

where

$F A N=$ free ammonia nitrogen concentration $\left(\mathrm{mg} \mathrm{L}^{-1}\right)$;

$T A N=$ total ammonia nitrogen concentration $\left(\mathrm{mg} \mathrm{L}^{-1}\right)$

$T=$ temperature $(\mathrm{K})$

$p H=$ hydrogen ionic potential

All analyses were performed in triplicate and standard deviation was $<10 \%$.

The biogas was conducted to a gas analyzer system and the methane content in the biogas was measured in real time using a data acquisition software (Bluesens BACVis software version 7.6.2.1).

The digested and precipitated sludges resulting from the biomethanation experiment were collected and washed with distilled water by centrifugation, to eliminate impurities and soluble salts. The washing process consisted of three washing cycles of the digested sludge with distilled water (1:2, in volume). Each washing cycle was carried out for 15 min, at $4500 \mathrm{rpm}$. Thereafter, the sludge was overdried for $36 \mathrm{~h}$ at $40^{\circ} \mathrm{C}$.

The elemental composition was assessed using Scanning Electron Microscopy with Energy Dispersive Spectroscopy (SEM-EDS Hitashi SU1510) and the crystallization products were characterized by X-ray diffraction using a high resolution X-ray Diffractometer (Bruker D8 Advance Davince) with $\mathrm{Cu} \mathrm{K} \alpha$ radiation $(\lambda=1.5406 \AA)$ produced at $40 \mathrm{~mA}$ and $40 \mathrm{kV}$. Data were collected in the $2 \theta$ range between $10^{\circ}$ and $80^{\circ}$ with a $2 \theta$-step size of $0.0260^{\circ}$ per second. The identification of crystalline structures was performed using EVA software V.4.0 from Bruker AXS. 


\section{Discussion}

\subsection{Struvite Precipitation Optimization Batch Assays}

The initial characterization of the mixture of substrates in the five experiments is summarized in Table 3.

Table 3. Initial characterization of the mixture of substrates.

\begin{tabular}{|c|c|c|c|c|c|c|c|}
\hline $\mathrm{TS}\left(\mathrm{g} \mathrm{L}^{-1}\right)$ & VS $\left(\mathrm{g} \mathrm{L}^{-1}\right)$ & $\operatorname{tCOD}\left(\mathrm{g} \mathrm{L}^{-1}\right)$ & $\operatorname{sCOD}\left(\mathrm{g} \mathrm{L}^{-1}\right)$ & $\mathrm{PO}_{4}^{3--} \mathrm{P}\left(\mathrm{g} \mathrm{L}^{-1}\right)$ & $\mathrm{NH}_{4}{ }^{+}-\mathrm{N}\left(\mathrm{g} \mathrm{L}^{-1}\right)$ & $\mathrm{C} / \mathrm{N}$ & $\mathrm{pH}$ \\
\hline $20 \pm 1$ & $16 \pm 2$ & $16.3 \pm 0.25$ & $2.04 \pm 0.45$ & $0.37 \pm 0.01$ & $0.67 \pm 0.00$ & $4 \pm 0.1$ & $7.5 \pm 0.1$ \\
\hline
\end{tabular}

From the results presented in Table 3, it is important to highlight the very low $\mathrm{C} / \mathrm{N}$ ratio $(4 \pm 0.1)$ of the mixture of substrates, as well as the high TS concentration $(20 \pm 1 \mathrm{~g}$ $\left.\mathrm{L}^{-1}\right)$, the fraction of volatile solids being $80 \%$, approximately $\left(16 \pm 2 \mathrm{~g} \mathrm{~L}^{-1}\right)$. Despite the high COD, only $12 \%$, approximately, corresponds to dissolved compounds $\left(2.04 \pm 0.45 \mathrm{~g} \mathrm{~L}^{-1}\right)$, suggesting that methane production may be limited by solubilization of particulate organic matter.

\subsubsection{Kinetics of the Struvite Precipitation Process}

As mentioned before, in the struvite precipitation experiments, the $\mathrm{pH}$ was monitored, at the beginning of the experiment and every 20 or $30 \mathrm{~min}$, during the reaction time (Figure 1). After each measurement, the $\mathrm{pH}$ of the mixture was adjusted to 8.5 by dropwise addition of $\mathrm{NaOH}(1 \mathrm{M})$, whenever necessary.

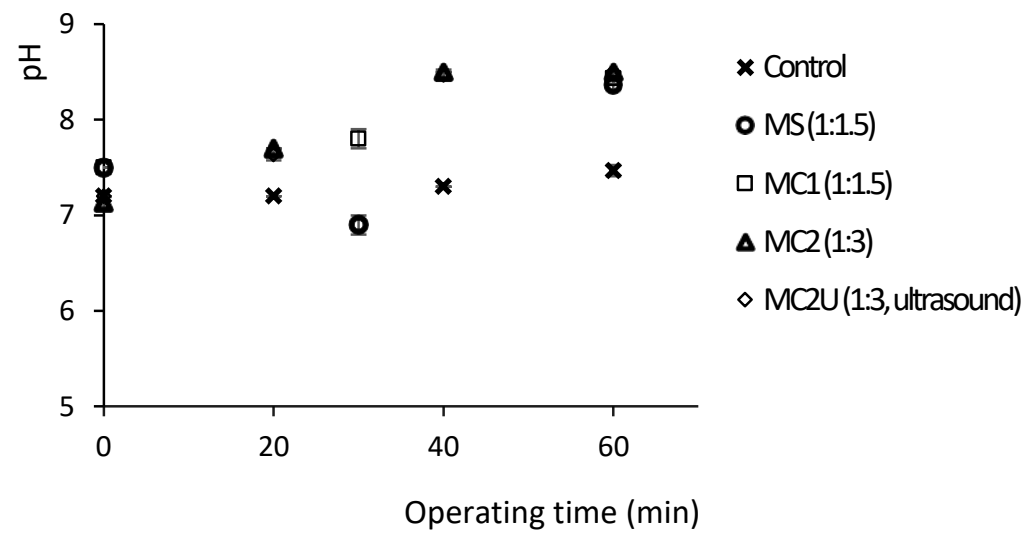

Figure 1. The $\mathrm{pH}$ profile along the reaction time.

At the beginning of the experiment, whenever the $\mathrm{pH}$ was adjusted to 8.5, a sudden decrease relatively to this threshold value was observed (Figure 1). This can be explained by the release of $\mathrm{H}^{+}$in the solution, as struvite precipitates, lowering the $\mathrm{pH}$ [29]. After 40 min of reaction, a tendency to a linear $\mathrm{pH}$ profile (around 8.5) was, in general, observed. These results suggest that the ions $\mathrm{PO}_{4}{ }^{3-}, \mathrm{NH}_{4}{ }^{+}$, and $\mathrm{Mg}^{2+}$, which are participating in struvite crystallization process, are being removed from the liquid phase due to struvite precipitation, until the reaction reaches the equilibrium, after $40 \mathrm{~min}$, under the tested conditions (Figure 1).

The average operating time to achieve the highest removal efficiencies of macronutrients through struvite precipitation reported in the literature varies considerably. Battistoni et al. (2001) [30] reported nutrient removal from anaerobically digested sludge higher than $80 \%$ through crystallization in about 100 min. Pullmmanappallil et al. (2001) [31] developed a process for nutrient recovery through struvite precipitation in a sequential batch reactor and recommended a reaction time below $30 \mathrm{~min}$. The high water-solubility of both sources of magnesium (marine salt and magnesium chloride) was considered to 
be a key enabling factor for the struvite precipitation process, contributing to shorten the overall reaction time.

The $\mathrm{PO}_{4}{ }^{3-}-\mathrm{P}$ and $\mathrm{NH}_{4}{ }^{+}-\mathrm{N}$ removal efficiencies obtained in the struvite precipitation experiments are depicted in Figure 2.

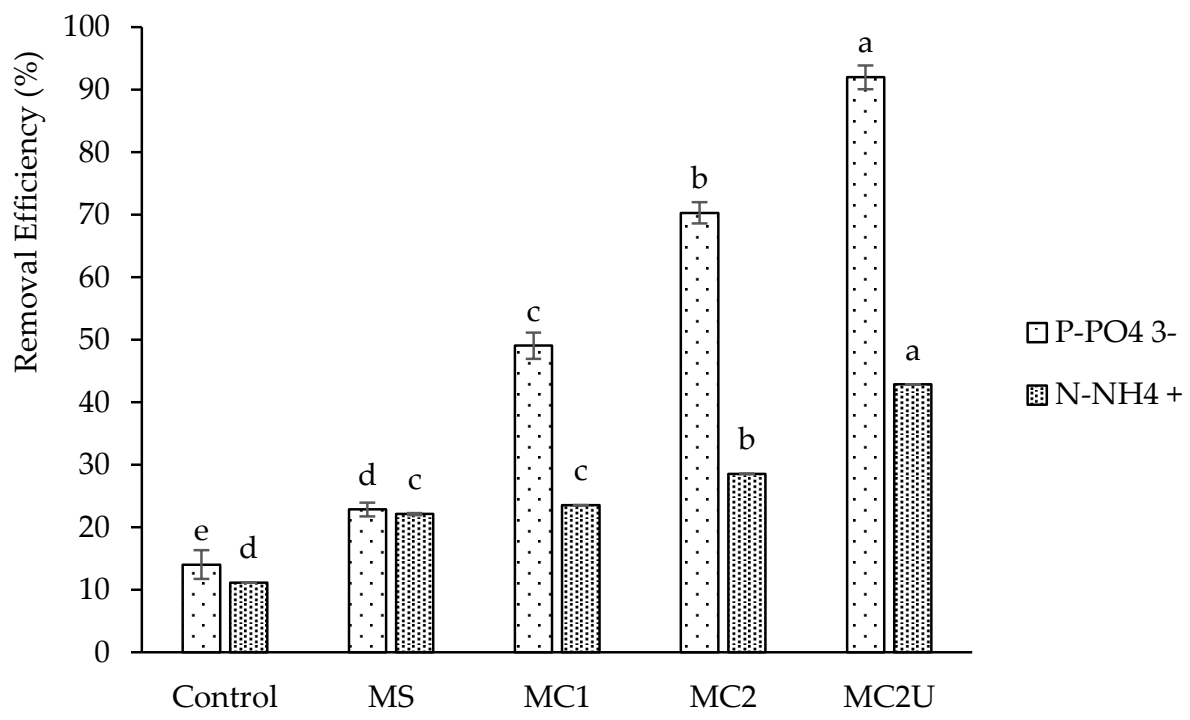

Figure 2. Ammonium nitrogen and orthophosphate removal efficiencies. (MS: marine salt as $\mathrm{Mg}$ source, $\mathrm{NH}_{4}{ }^{+}: \mathrm{Mg}^{2+}$ of 1:1.5; $\mathrm{MC1}: \mathrm{MgCl}_{2}$ as $\mathrm{Mg}$ source, $\mathrm{NH}_{4}{ }^{+}: \mathrm{Mg}^{2+}$ of 1:1.5; $\mathrm{MC}^{2} \mathrm{MgCl}_{2}$ as $\mathrm{Mg}$ source, $\mathrm{NH}_{4}{ }^{+}: \mathrm{Mg}^{2+}$ of 1:3; $\mathrm{MC} 2 \mathrm{U}: \mathrm{MgCl}_{2}$ as $\mathrm{Mg}$ source, $\mathrm{NH}_{4}{ }^{+}: \mathrm{Mg}^{2+}$ of 1:3 and ultrasound pretreatment). Different letters above bars indicate significant differences (Duncan's test; $p<0.05$ ).

Control assays (with no external magnesium source) revealed $\mathrm{PO}_{4}{ }^{3-}-\mathrm{P}$ and $\mathrm{NH}_{4}{ }^{+}-\mathrm{N}$ removal efficiencies of $15 \%$ and $11 \%$, respectively (Figure 2). Since no source of magnesium was added to promote the formation of struvite in the control assays, $\mathrm{NH}_{4}{ }^{+}-\mathrm{N}$ losses may be due to stripping processes favored by high $\mathrm{pH}$ values [32]. The observed orthophosphate removal may be explained by the uptake by biomass present in the substrates [33].

As depicted in Figure 2, decreasing the $\mathrm{NH}_{4}{ }^{+}$to $\mathrm{Mg}^{2+}$ molar ratio from 1:1.5 to 1:3 led to a slight increase in nitrogen removal efficiency (29\% in experiment MC2 and $23 \%$ in MC1; $p<0.05)$. Simultaneously, the orthophosphate removal efficiency significantly increased by approximately $61 \%$ (from $32 \%$ in MC1 to $50 \%$ in MC2). A comparison between MC1 and MS assays shows significant differences in the orthophosphate removal efficiencies $(32 \%$ and $23 \%$ respectively) but not on the TAN removal efficiencies ( $23 \%$ and $22 \%$, respectively). This result is in accordance with the studies performed by Pinatha et al. (2020) [34], demonstrating that marine salt formed struvite $18 \%$ less than did $\mathrm{MgCl}_{2}$. The low values of $\mathrm{N}$ and $\mathrm{P}$ removal efficiencies obtained when marine salt was used as external Mg source may probably be related to the presence of sea salt crystals when this resource was used to provide the $\mathrm{Mg}^{2+}$ concentration required for struvite precipitation, indicating that the amount of dissolved magnesium was insufficient for an efficient nutrient recovery.

The application of ultrasound (SE of 10,180 kJ kgTS-1) prior to struvite precipitation, in MC2U experiment, led to an increase of $38 \%$ in TAN concentration (from $710 \pm 98 \mathrm{mg}$ $\mathrm{L}^{-1}$ in MC2 to $980 \pm 68 \mathrm{mg} \mathrm{L}^{-1}$ in MC2U) (Table 4). Similar values were observed by Bougrier et al. (2005) [35], who reported an increase of $40 \%$ in organic nitrogen solubilization after ultrasonic treatment of waste-activated sludge with a specific energy input of 15,000 kJ $\mathrm{kgTS}^{-1}$. Salsabil et al. (2005) [36] observed a linear increase in total nitrogen solubilization with increasing specific energy, for specific energies above $3600 \mathrm{~kJ} \mathrm{kgTS}^{-1}$, reaching $19.6 \%$ 
for a specific energy of $108,000 \mathrm{~kJ} \mathrm{kgTS}^{-1}$. The effect of sonication on phosphorus behaviour is rarely described in literature. Following the trend reported by Salsabil et al. (2005) [36], the ultrasound pretreatment applied in MC2U experiment also increased phosphorus solubility. In fact, an increase of $85 \%$ in orthophosphate concentration was observed, from $389 \pm 3 \mathrm{mg} \mathrm{L}^{-1}$ in $\mathrm{MC} 2$ to $719 \pm 3 \mathrm{mg} \mathrm{L}^{-1}$ in MC2U.

Table 4. The ammonium nitrogen and orthophosphate concentration. $(\mathrm{Ti}=$ Initial time; $\mathrm{Tf}=$ Final time; Tau $=$ after ultrasound pretreatment; Tas = after struvite treatment.

\begin{tabular}{|c|c|c|c|}
\hline & & TAN (mg L-1) & Orthophosphate (mg L-1) \\
\hline \multirow[t]{2}{*}{ Control } & $\mathrm{Ti}$ & $630 \pm 10$ & $480 \pm 16$ \\
\hline & $\mathrm{Tf}$ & $560 \pm 12$ & $406 \pm 11$ \\
\hline \multirow[t]{2}{*}{ MS } & $\mathrm{Ti}$ & $630 \pm 6$ & $433 \pm 9$ \\
\hline & Tas & $491 \pm 13$ & $334 \pm 22$ \\
\hline \multirow[t]{2}{*}{ MC1 } & $\mathrm{Ti}$ & $636 \pm 11$ & $467 \pm 5$ \\
\hline & Tas & $486 \pm 8$ & $318 \pm 19$ \\
\hline \multirow[t]{2}{*}{ MC2 } & $\mathrm{Ti}$ & $490 \pm 13$ & $348 \pm 11$ \\
\hline & Tas & $350 \pm 11$ & $175 \pm 4$ \\
\hline \multirow[t]{3}{*}{ MC2U } & $\mathrm{Ti}$ & $710 \pm 98$ & $389 \pm 3$ \\
\hline & Tau & $980 \pm 68$ & $719 \pm 3$ \\
\hline & Tas & $560 \pm 23$ & $58 \pm 7$ \\
\hline
\end{tabular}

The highest orthophosphate and TAN removal efficiencies $(92 \%$ and $43 \%$, respectively) were obtained when the ultrasound treatment was applied prior to struvite precipitation (MC2U). Several authors reported ammonium nitrogen removal efficiencies higher than $90 \%$ when the process of struvite precipitation was applied as post-treatment, after the anaerobic digestion $[37,38]$. This can be explained by the enhanced availability of $\mathrm{N}-\mathrm{NH}_{4}{ }^{+}$and $\mathrm{P}_{-} \mathrm{PO}_{4}{ }^{3-}$ as result of the mineralization of organic compounds that occurs during anaerobic digestion, thus increasing the potential for struvite precipitation [39].

\subsection{Biomethanization Assays}

In order to assess the effect of pretreatment of substrates on methane production in anaerobic sequencing batch reactors, biomethanation experiments were performed using cattle slurry liquid fraction and sewage sludge as substrates, as previously described in Section 2.2. The main physical and chemical characteristics of the substrates (CSLF, SwS) and the inoculum are presented in Table 5.

Table 5. Substrates and inoculum characterization.

\begin{tabular}{cccc}
\hline Parameter & SwS & CSLF & Inoculum \\
\hline TS $\left(\mathrm{g} \mathrm{L}^{-1}\right)$ & $9.7-24.0$ & $13.8-26.1$ & $14.0-17.2$ \\
VS $\left(\mathrm{g} \mathrm{L}^{-1}\right)$ & $7.3-20.1$ & $8.0-19$ & $10.4-13.6$ \\
TOC $\left(\mathrm{g} \mathrm{L}^{-1}\right)$ & $4.0-11.2$ & 10.8 & $5.8-7.5$ \\
tCOD $\left(\mathrm{g} \mathrm{L}^{-1}\right)$ & $24.8-47.7$ & $8.8-32.0$ & $9.6-21.9$ \\
sCOD $\left(\mathrm{g} \mathrm{L}^{-1}\right)$ & $2.6-6.6$ & $2.6-9.1$ & $0.4-1.0$ \\
TKN $\left(\mathrm{g} \mathrm{L}^{-1}\right)$ & $3.2-3.9$ & $3.5-3.6$ & $3.0-5.0$ \\
TAN $\left(\mathrm{mg} \mathrm{L}^{-1}\right)$ & 952 & $840-1317$ & $854-1513$ \\
FAN $\left(\mathrm{mg} \mathrm{L}^{-1}\right)$ & $0.04-13.29$ & $7-28$ & $18.74-33.18$ \\
PO $4^{3-}-\mathrm{P}\left(\mathrm{mg} \mathrm{L}^{-1}\right)$ & $224-728$ & $205-634$ & $854-1513$ \\
$\mathrm{pH}$ & $5.2-7.1$ & 6.9 & 7.3 \\
\hline
\end{tabular}

The results presented in Table 5 demonstrate the complexity, but also the potential for nutrient and energy recovery of the substrates used in the present study, with high 
nitrogen, phosphorus and organic matter concentrations. The volatile solid content represented 75 to $83 \%$ of the total solids in the SwS and 58 to $73 \%$ of the TS in the CSLF. Nevertheless, despite the high COD levels, the soluble fractions correspond to $10-14 \%$ and 28 $-30 \%$ on SwS and CSLF, respectively.

Table 6 presents the characterization of the mixture of substrates before $\left(\mathrm{T}_{\mathrm{Bu}}\right)$ and after $\left(\mathrm{T}_{\mathrm{AU}}\right)$ ultrasound treatment and after struvite precipitation treatment $\left(\mathrm{T}_{\mathrm{AS}}\right)$ of the mixture of substrates previously treated with ultrasound.

Table 6. Characterization of the mixture of substrates before ( $\left.\mathrm{T}_{\mathrm{BU}}\right)$ and after $\left(\mathrm{T}_{\mathrm{AU}}\right)$ ultrasound pre-treatment and after struvite treatment $\left(\mathrm{T}_{\mathrm{AS}}\right)$, prior to reactor inoculation.

\begin{tabular}{|c|c|c|c|c|c|c|c|c|}
\hline $\begin{array}{c}\text { Biomethanation } \\
\text { Experiment }\end{array}$ & & $\begin{array}{l}\text { CODs } \\
\left(\mathrm{mg} \mathrm{L}^{-1}\right)\end{array}$ & $\begin{array}{c}\text { TAN } \\
\left(\mathrm{mg} \mathrm{L}^{-1}\right)\end{array}$ & $\begin{array}{c}\text { FAN } \\
\left(\mathrm{mg} \mathrm{L}^{-1}\right)\end{array}$ & $\begin{array}{c}\mathrm{PO}_{4}^{3-} \\
\left(\mathrm{mg} \mathrm{L}^{-1}\right)\end{array}$ & $\begin{array}{c}\mathrm{ST} \\
\left(\mathrm{g} \mathrm{L}^{-1}\right)\end{array}$ & $\begin{array}{c}\mathrm{VS} \\
\left(\mathrm{g} \mathrm{L}^{-1}\right)\end{array}$ & $\begin{array}{c}\mathrm{SS} \\
\left(\mathrm{g} \mathrm{L}^{-1}\right)\end{array}$ \\
\hline ASBR1: Control & & $1280.0 \pm 122$ & $311.6 \pm 5$ & $8.6 \pm 0.1$ & $481 \pm 5.4$ & $16.0 \pm 1.4$ & $9.9 \pm 0.1$ & $13.2 \pm 4.5$ \\
\hline \multirow{3}{*}{ ASBR2: US + SP } & $\mathrm{T}_{\mathrm{BU}}$ & $2240.0 \pm 80$ & $700.3 \pm 99$ & $2.5 \pm 0.3$ & $589 \pm 3.6$ & $26.6 \pm 1.1$ & $19.9 \pm 1.0$ & $9.6 \pm 0.6$ \\
\hline & $\mathrm{T}_{\mathrm{AU}}$ & $3920.0 \pm 113$ & $735.4 \pm 49$ & $2.6 \pm 0.2$ & $611 \pm 32.2$ & $29.3 \pm 1.6$ & $21.9 \pm 1.4$ & $9.3 \pm 0.1$ \\
\hline & $\mathrm{T}_{\mathrm{AS}}$ & $4480.0 \pm 93$ & $560.3 \pm 99$ & - & $557 \pm 2.9$ & $38.4 \pm 0.1$ & $30.8 \pm 0.1$ & $8.8 \pm 0.4$ \\
\hline \multirow{3}{*}{ ASBR3: US/2 + SP } & $\mathrm{T}_{\mathrm{BU}}$ & $2240.0 \pm 86$ & $595.3 \pm 49$ & - & $252.0 \pm 3.6$ & $25.5 \pm 0.9$ & $18.6 \pm 0.5$ & $25.8 \pm 0.1$ \\
\hline & $\mathrm{T}_{\mathrm{AU}}$ & $3205.0 \pm 99$ & $630.3 \pm 99$ & - & $360 \pm 10.9$ & $21.2 \pm 0.1$ & $15.6 \pm 0.1$ & $20.3 \pm 0.8$ \\
\hline & $\mathrm{T}_{\mathrm{AS}}$ & - & $490.2 \pm 89$ & - & $209 \pm 2.2$ & $39.3 \pm 0.1$ & $24.7 \pm 0.1$ & $18.1 \pm 0.1$ \\
\hline
\end{tabular}

After treatment with ultrasound, the sCOD in the mixture of substrates increased $75 \%$ and $43 \%$, when the specific energy was $8180 \mathrm{~kJ} \mathrm{kgTS}^{-1}$ (ASBR2) and $4270 \mathrm{~kJ} \mathrm{kgTS-1}$ (ASBR3), respectively. The TAN concentration slightly increased $5 \%$ on both assays (ASBR2 and ASBR3). With struvite precipitation, the $\mathrm{NH}_{4}{ }^{+}-\mathrm{N}$ removal efficiency increased $20 \%$ in both reactors, after ultrasound pretreatment. This can be explained by enhanced solubilization of nitrogen compounds due to sonication and increased availability of ammonium nitrogen for struvite formation.

Table 7 presents the initial physicochemical characterization of the mixed liquor in all the anaerobic sequencing batch reactors (ASBR), after inoculation, in terms of $\mathrm{pH}$, TS and VS, total and dissolved organic matter as COD, TKN, TAN, and FAN. Some operational parameters are also depicted in Table 7, namely the applied organic load rate (OLR) (as COD and VS), methane yield ( $\mathrm{Y}_{\mathrm{CH} 4 / \mathrm{NS})}$ and methane content in the biogas, maximum observed biodegradation rate, maximum observed methane production rate, and the hydraulic retention time (HRT).

Table 7. Physicochemical characterization of the mixed liquor in the ASBR.

\begin{tabular}{|c|c|c|c|}
\hline Parameter & ASBR1 & ASBR2 & ASBR3 \\
\hline $\mathrm{pH}$ & $7.4 \pm 0.1$ & $7.8 \pm 0.1$ & $7.7 \pm 0.1$ \\
\hline $\mathrm{TS}\left(\mathrm{g} \mathrm{L}^{-1}\right)$ & $16.0 \pm 1$ & $34.1 \pm 0.8$ & $31.2 \pm 0.5$ \\
\hline $\mathrm{VS}\left(\mathrm{g} \mathrm{L}^{-1}\right)$ & $10.0 \pm 0.1$ & $22.3 \pm 0.8$ & $19.0 \pm 0.5$ \\
\hline $\mathrm{OM}(\%)$ & $62.4 \pm 0.1$ & $65.3 \pm 0.1$ & $62.0 \pm 0.1$ \\
\hline $\mathrm{tCOD}\left(\mathrm{mg} \mathrm{L}^{-1}\right)$ & $24128 \pm 269$ & $38495 \pm 2102$ & $32013 \pm 336$ \\
\hline $\mathrm{sCOD}\left(\mathrm{mg} \mathrm{L}^{-1}\right)$ & $1280.0 \pm 0.1$ & $1600.0 \pm 101$ & $1440.0 \pm 226$ \\
\hline TKN (mg L-1) & $1225.6 \pm 0.1$ & $1435.7 \pm 42$ & $1295.6 \pm 36$ \\
\hline TAN (mg L $\left.{ }^{-1}\right)$ & $311.7 \pm 5$ & $420.2 \pm 26$ & $490.2 \pm 89$ \\
\hline FAN (mg L $\left.{ }^{-1}\right)$ & $8.6 \pm 0.1$ & $27.8 \pm 0.1$ & $26.1 \pm 5$ \\
\hline FAN/TAN (\%) & $2.7 \pm 0.1$ & $6.6 \pm 0.1$ & $5.3 \pm 0.1$ \\
\hline $\mathrm{PO}_{4}^{3-}-\mathrm{P}\left(\mathrm{mg} \mathrm{L}^{-1}\right)$ & $481.0 \pm 5$ & $526.2 \pm 0.1$ & $203.3 \pm 2.9$ \\
\hline $\mathrm{C} / \mathrm{N}$ & $5.0 \pm 0.1$ & $8.6 \pm 0.1$ & $8.1 \pm 0.1$ \\
\hline OLR $\left(\mathrm{kgCOD} \mathrm{m}^{-3} \mathrm{~d}^{-1}\right)$ & $0.2 \pm 0.1$ & $7.0 \pm 0.1$ & $0.6 \pm 0.1$ \\
\hline OLR $\left(\mathrm{gVS} \mathrm{L}^{-1} \mathrm{~d}^{-1}\right)$ & $0.15 \pm 0.1$ & $0.47 \pm 0.1$ & $0.38 \pm 0.1$ \\
\hline Methane content in biogas (\%) & 33 & 60 & 57 \\
\hline
\end{tabular}




\begin{tabular}{cccc} 
Maximum observed biodegradation rate rate $\left(\mathrm{g} \mathrm{L}^{-1} \mathrm{~d}^{-1}\right)$ & 0.17 & 0.53 & 0.64 \\
Maximum observed methane production rate $\left(\mathrm{mL} \mathrm{g}^{-1} \mathrm{~d}^{-1}\right)$ & 77 & 643 & 743 \\
YCH4 (mLCH $\left.\mathrm{gVS}^{-1}\right)$ & 26.5 & 48.5 & 32.2 \\
HRT (d) & 66 & 47 & 49 \\
\hline
\end{tabular}

It is important to notice that despite the $\mathrm{pH}$ being adjusted to 8.5 during the struvite precipitation process, after inoculation, the $\mathrm{pH}$ values decreased ranging between 7.4 and 7.8 in the bioreactors (Table 7), which is in the range of the optimal $\mathrm{pH}$ (6.5 to 8.5) reported by different authors [2,40].

A comparison between ASBR1 (control) and ASBR2 experiments revealed that treatment with ultrasound followed by struvite precipitation resulted in an increase in $\mathrm{C} / \mathrm{N}$ ratio from 5.0 to 8.6, as well as in FAN/TAN from 2.7 to 6.6, leading to an increase in the biogas methane content of $83 \%$ (from 33 to $60 \%$ ). In ASBR3, a similar pattern was observed, the $\mathrm{C} / \mathrm{N}$ ratio being increased from 5.0 to 8.1 and FAN/TAN from 2.7 to 5.3, thus increasing the methane content in the biogas by $74 \%$ (from 33 to $57 \%$ ). Moreover, a reduction in the hydraulic retention time was observed in both reactors $(28 \%$ and $25 \%$ in ASBR2 and ASBR3, respectively). In fact, the low $\mathrm{C} / \mathrm{N}$ ratio observed in ASBR1 is related to a lower maximum observed degradation rate $\left(0.17 \mathrm{~g} \mathrm{~L}^{-1} \mathrm{~d}^{-1}\right)$ and a lower maximum observed methane production rate $\left(77 \mathrm{~mL} \mathrm{~g}^{-1} \mathrm{~d}^{-1}\right)$. This is in accordance with the lower final methane yield (26.5 $\left.\mathrm{mLCH}_{4} \mathrm{gVS}^{-1}\right)$ and lower methane content in biogas (33\%) suggesting that methanogenesis was partially inhibited. However, despite the higher maximum observed degradation rate $\left(0.64 \mathrm{~g} \mathrm{~L}^{-1} \mathrm{~d}-1\right)$ and maximum observe methane production rate (743 $\mathrm{mL} \mathrm{g}^{-1} \mathrm{~d}^{-1}$ ) obtained in ASBR 3, the methane content in biogas were similar to ASBR 2 (Table 7), indicating that the methanogenesis was not hindered. This kinetics parameters are higher than those reported by Mao et al. (2017) [41] and Nutongkaew et al. (2020) [42], $12 \mathrm{~mL} \mathrm{~g}^{-1} \mathrm{~d}^{-1}$ and $50 \mathrm{~mL} \mathrm{~g}^{-1} \mathrm{~d}^{-1}$, respectively, suggesting that the combined treatment with ultrasound and struvite precipitation leads to an enhancement of the biomethanization process.

With the overall pretreatment process (ultrasound followed by struvite precipitation), it was possible to overcome the $\mathrm{C} / \mathrm{N}$ unbalance, resulting in a higher efficiency of the anaerobic co-digestion process in terms of methane production, as well as total COD and volatile solids removal efficiency (Figure 3).

The content in methane of the biogas produced in reactors ASBR2 and ASBR3 was similar, around $60 \%$. However, the conversion efficiency of vs. to methane decreased by $44 \%$ (from $48.5 \mathrm{mLCH}_{4} \mathrm{gVS}^{-1}$ to $32.2 \mathrm{mLCH}_{4} \mathrm{gVS}^{-1}$ ) when the energy input was reduced from $218 \mathrm{~kJ} \mathrm{~L}^{-1}\left(\mathrm{SE}=8180 \mathrm{~kJ} \mathrm{kgTS}^{-1}\right)$ to $109 \mathrm{~kJ} \mathrm{~L}^{-1}\left(\mathrm{SE}=4270 \mathrm{~kJ} \mathrm{kgTS}^{-1}\right)$. The low methane yields (in $\mathrm{mL} \mathrm{gVS}^{-1}$ ) obtained in the present study may be explained by the very high initial volatile solids concentration, ranging between 10 and $22.3 \mathrm{~g} \mathrm{~L}^{-1}$ (as depicted in Table 7). However, despite de high initial vs. concentration, a removal efficiency of only $13-24 \%$ was observed, leading to a low methane yield, in $\mathrm{mL} \mathrm{gVS}^{-1}$.

Despite the high content of methane $(60 \%)$ in the biogas produced in reactors ASBR2 and ASBR3 and the higher COD removal efficiencies (60 and 50\%, respectively), when compared to ASBR1 (control without substrates pretreatment), the treated effluent still presents a very high COD content, $6200 \mathrm{mg} \mathrm{L}^{-1}$ and $5012 \mathrm{mg} \mathrm{L}^{-1}$, in ASBR 2 and ASBR3, respectively, as well as nitrogen and phosphorus, indicating the need of a post-treatment before wastewater discharge according to Portuguese law (DL 236/98, of 1 August). 


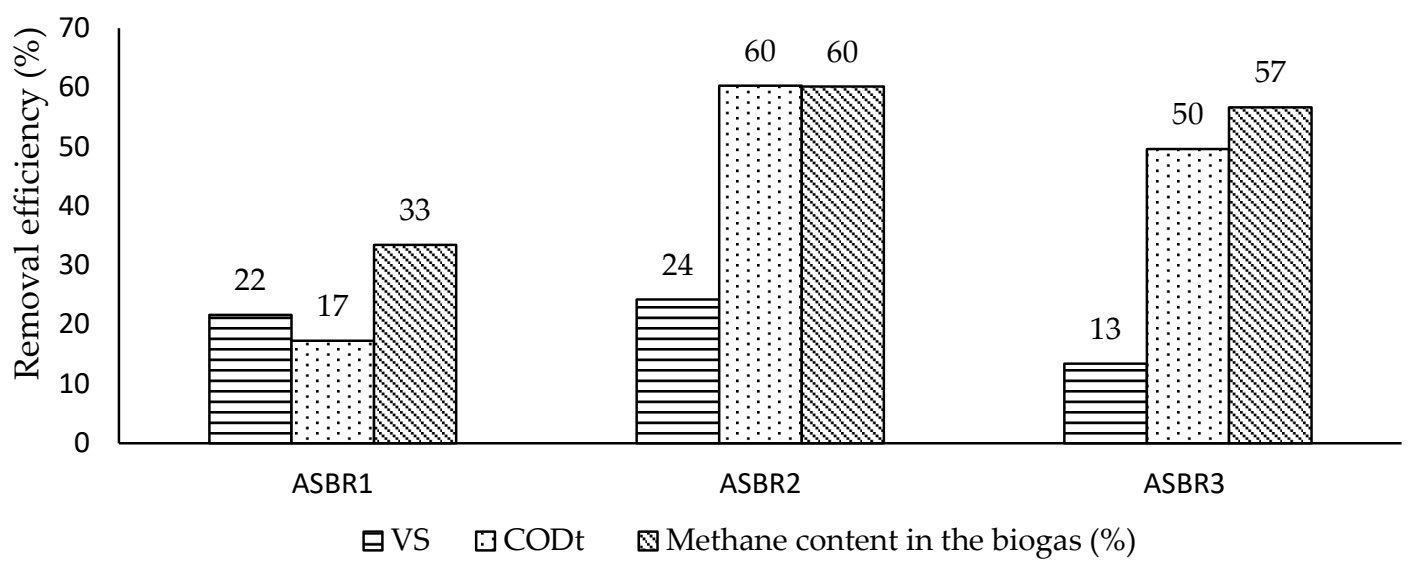

Figure 3. Methane content in the biogas. tCOD and vs. removal efficiencies obtained in the ASBR experiments.

Scanning Electron Microscopy with Energy Dispersive Spectroscopy analysis (Figure 4), suggest that the heterogeneity of the samples presented itself as an obstacle in the identification and quantification of the formed compounds, mainly due to the very high solids content, typical of the SwS and CSLF, originating a sludge-containing struvite crystals. In fact, beside struvite crystals, the formation of other compounds such as newberyite $\left(\mathrm{MgHPO}_{4} \cdot 3 \mathrm{H}_{2} \mathrm{O}\right)$, monetite $\left(\mathrm{CaHPO}_{4}\right)$, brushite $\left(\mathrm{CaHPO}_{4} \cdot 2 \mathrm{H}_{2} \mathrm{O}\right)$, may have occurred as a consequence of $\mathrm{pH}$ variations and the presence of ions such as $\mathrm{Ca}_{2}{ }^{+}$and $\mathrm{Mg}_{2}{ }^{+}$[43]. Therefore, the characterization of the precipitates occurred in two steps, the former supported on SEM analysis in order to identify the main elements present in the samples, and the latter based on crystals characterization by X-ray diffraction.

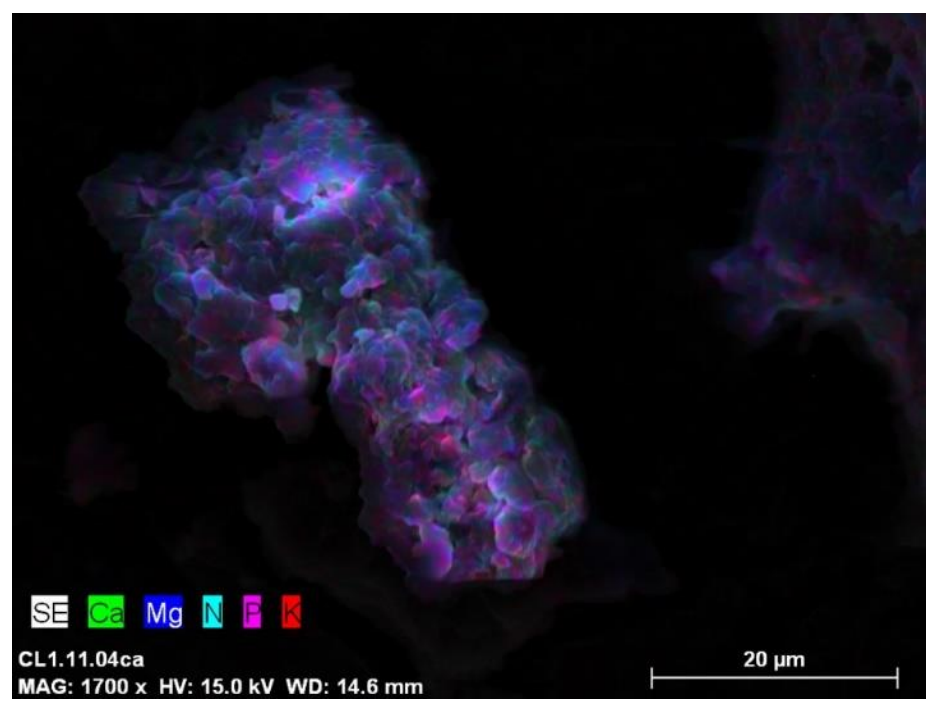

Figure 4. SEM-EDS microphotography of the precipitates formed.

In a sample collected in ASBR2, 72\% corresponded to water-soluble compounds that were removed after the washing process. The X-ray analyses of the sample collected in ASBR2, after washing and drying, as described in Section 2.3, confirmed the presence of struvite (Figure 5). 


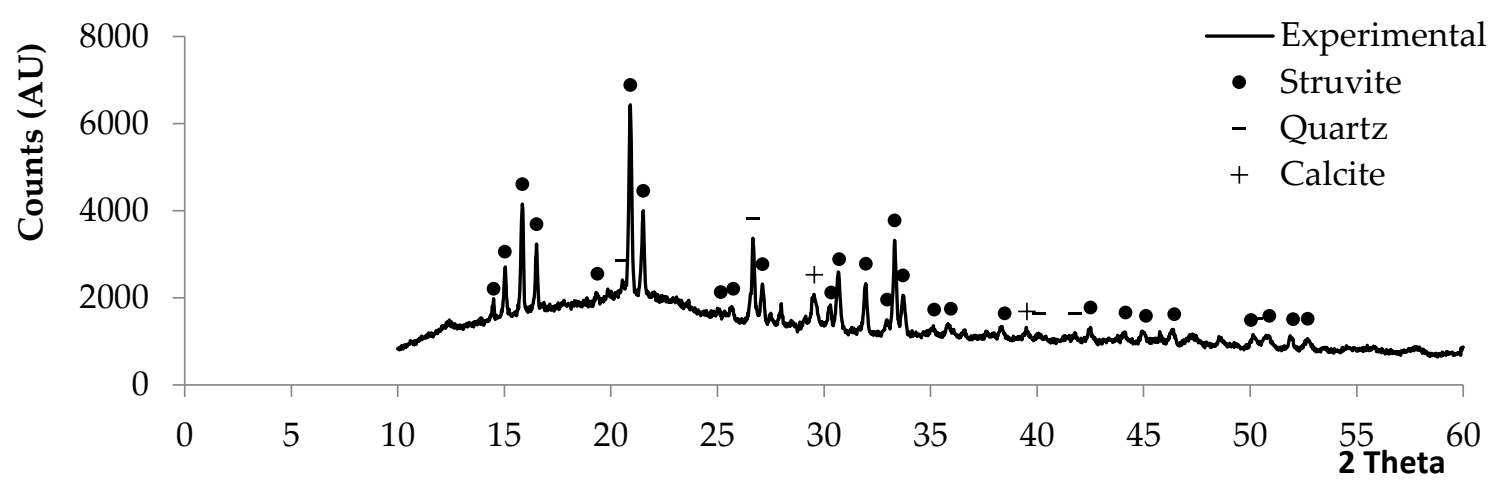

Figure 5. XRD difractogram of the sludge collected from ASBR2 experiment. previously washed and dried.

Approximately $85 \%$ of the digested sludge sample, previously washed and dried, was quantified as struvite, The $\mathrm{X}$-ray diffraction also indicated correlating peaks for both quartz ( $\mathrm{SiO} 2)$ and calcite $(\mathrm{CaCO} 3)$, but in smaller quantities (8 and 7\%, respectively). The quartz ( $\mathrm{SiO} 2$ ) is a compound naturally found in both substrates ( $\mathrm{SwS}$ and CSLF), given the nature of the agro-industrial activities that origin such waste and/or wastewater. According to $[43,44]$, magnesium containing species and species containing calcium are ion and $\mathrm{pH}$ dependent and can also be formed under similar conditions to the struvite precipitation process, which may explain the presence of calcite.

Considering the heterogeneity of the sludge sample, the semi-quantitative analyses obtained by X-ray and the treatment conditions in ASBR2 and ASBR3, it is possible to suggest that, approximately $230 \mathrm{~g} \mathrm{~L}^{-1}$ and $100 \mathrm{~g} \mathrm{~L}^{-1}$ of struvite, respectively, can be obtained.

\section{Conclusions}

When ammonium drives anaerobic processes inhibition, nitrogen removal through struvite precipitation, as pretreatment, may have a positive effect on methanogenesis. Since the ultimate goal was primarily to remove $\mathrm{NH}_{4}{ }^{+}-\mathrm{N}$, the results obtained were favorable from this perspective and the combined ultrasound and struvite precipitation pretreatment has shown to be a feasible option to enhance further bioenergy processes.

The following conclusions may be highlighted from the struvite precipitation experiment:

- the reaction time of $40 \mathrm{~min}$ seems to be suitable for crystallization and precipitation of struvite using a mixture of urban WWTP sludge and cattle slurry liquid fraction as substrate;

- to fulfill the stoichiometric requirements of magnesium, high amounts of marine salt are necessary, resulting in the presence of insoluble crystals, which may limit nutrient recovery processes;

- the ammonium nitrogen and orthophosphate removal efficiencies increased when the $\mathrm{NH}_{4}^{+}: \mathrm{Mg}^{2+}$ stoichiometric ratio decreased from 1:1.5 to 1:3. reaching $29 \%$ and $50 \%$, respectively;

- the application of ultrasound to the mixture of substrates, prior to the struvite precipitation process, resulted in an increase in ammonium nitrogen and orthophosphate removal efficiencies, reaching $43 \%$ and $92 \%$, respectively, as a result of the increase in the solubilization rate of organic compounds;

Regarding the biomethanation experiment, the main conclusions are as follows:

- treatment of the substrates with ultrasound (either with a EI of $109 \mathrm{~kJ} \mathrm{~L}^{-1}$ (SE of 4270 $\mathrm{kJ} \mathrm{TS}^{-1}$ ) or EI of $218 \mathrm{~kJ} \mathrm{~L}^{-1}$ (SE of $\left.8180 \mathrm{~kJ} \mathrm{TS}^{-1}\right)$ ) resulted in an increase of $73-82 \%$ in methane content in the biogas (57-60\%) and a reduction in the HRT of $25-28 \%$;

- treatment of the substrates with ultrasound prior to struvite precipitation enhanced ammonium nitrogen removal and, consequently, increased methane yield; 
- the reduction of the energy input from $218 \mathrm{~kJ} \mathrm{~L}^{-1}$ (SE of $8180 \mathrm{~kJ} \mathrm{TS}^{-1}$ ) to $109 \mathrm{~kJ} \mathrm{~L}^{-1}$ (SE of $4270 \mathrm{~kJ} \mathrm{TS}^{-1}$ ) resulted in a decrease of $44 \%$ in methane yield (from $48.5 \mathrm{mLCH}_{4}$ $\mathrm{gVS}^{-1}$ to $32.2 \mathrm{mLCH}_{4} \mathrm{gVS}^{-1}$ ), despite de methane content in biogas remained similar $(60 \%)$;

- a combination of ultrasound (SE of $8180 \mathrm{~kJ} \mathrm{kgTS}^{-1}$ ) and struvite precipitation $\left(\mathrm{NH}_{4}: \mathrm{Mg}^{2+}\right.$ of 1:3) as pretreatment may be a feasible option to increase the efficiency of ACoD of SwS and CSLF in a context of nitrogen-rich systems, in terms of COD removal and methane production;

- the FAN/TAN ratio seems to be correlated to the methane production;

- TAN values lower than $311 \mathrm{mg}^{-1}$ seems to be unfavorable to the methanogenesis;

- the reduction of the energy input from $218 \mathrm{~kJ} \mathrm{~L}^{-1}$ (SE of $8180 \mathrm{~kJ} \mathrm{TS}^{-1}$ ) to $109 \mathrm{~kJ} \mathrm{~L}^{-1}$ (SE of $4270 \mathrm{~kJ} \mathrm{TS}^{-1}$ ) resulted in a semi-quantitative estimative of, approximately $230 \mathrm{~g} \mathrm{~L}^{-1}$ and $100 \mathrm{~g} \mathrm{~L}^{-1}$ of struvite, respectively.

Author Contributions: Conceptualization, R.D.C., A.C.R., J.M.A., A.I.F., and A.G.B.; validation, writing - review and editing and methodology, R.D.C., A.C.R., A.G.B., A.I.F., J.C.d.C.A., and L.M.B.; investigation, R.D.C. and A.C.R.; writing - original draft preparation, R.D.C.; supervision, A.C.R., J.M.A. and A.G.B. All authors have read and agreed to the published version of the manuscript.

Funding: This research was funded by the Conselho Nacional de Desenvolvimento Científico e Tecnológico (CNPq-Brazil) grant number GDE 201469/2014-6, which is gratefully acknowledged.

Institutional Review Board Statement: Not applicable.

Informed Consent Statement: Not applicable.

Data Availability Statement: The data presented in this study are available on request from the corresponding author. The data are not publicly available due to patent pending process.

Acknowledgments: We greatly appreciate the support of the research units Materials, Energy and Environment for Sustainability (ProMetheus) of IPVC (Portugal) and Linking Landscape, Environment, Agriculture and Food (LEAF) of ULisbon (Portugal). We likewise thank Francis E. Criss Jr. for the constructive comments on the manuscript. A.G. Brito acknowledge NitroPortugal, H2020TWINN-2015, EU coordination and support action n. 692331.

Conflicts of Interest: The authors declare no conflict of interest.

\section{References}

1. Yenigun, O.; Demirel, B. Ammonia inhibition in anaerobic digestion: A review. Process Biochem. 2013, 48, 901-911, doi:10.1016/j.procbio.2013.04.012.

2. Zhang, C.; Su, H.; Baeyens, J.; Tan, T. Reviewing the anaerobic digestion of food waste for biogas production. Renew. Sustain. Energy Rev. 2014, 38, 383-392, doi:10.1016/j.rser.2014.05.038.

3. Sawayama, S.; Tada, C.; Tsukahara, K.; Yagishita, T. Effect of ammonium adition on methanogenic community in a fluidized bed anaerobic digestion. J. Biosci. Bioeng. 2004, 97, 65-70, doi:10.1016/S1389-1723(04)70167-X.

4. Lauterbpcl, B.; Ortner, M.; Haider, R.; Fuchs, W. Counteracting ammonia inhibition in anaerobic digestion by removal with a hollow fiber membrane contactor. Water Resour. 2012, 46, 4861-4869, doi:10.1016/j.watres.2012.05.022.

5. Parameswaran, P.; Rittmann, B. Feasibility of anaerobic co-digestion of pig waste and paper sludge. Bioresour. Technol. 2012, 124, 163-168, doi:10.1016/j.biortech.2012.07.116.

6. Astals, S.; Peces, M.; Batstone, D.; Jensen, P.; Tait, S. Characterizing and modelling free ammonia and ammonium inhibition inanaerobic systems. Water Res. 2018, 143, 127-135, doi:10.1016/j.watres.2018.06.021.

7. Chen, Y.; Cheng, J.; Creamer, K. Inhibition of anaerobic digestion process: A review. Bioresour. Technol. 2008, 99, 4044-4064, doi:10.1016/j.biortech.2007.01.057.

8. Luostarinen, S.; Luste, S.; Sillanpaa, M. Increased biogas production at wastewater treatment plants through co-digestion of sewage sludge with grease trap sludge rom a meat processing plant. Bioresour. Technol. 2009, 100, 79-85, doi:10.1016/j.biortech.2008.06.029.

9. Xie, S.; Wickham, R.; Nghiem, L. Synergistic effect from anaerobic co-digestion of sewage sludge andorganic wastes. Int. Biodeterior. Biodegrad. 2017, 116, 191-197, doi:10.1016/j.ibiod.2016.10.037.

10. Elser, J.; Bennett, E. Phosphorus cycle: A broken biogeochemical cycle. Nature 2011, 478, 29-31, doi:10.1038/478029a.

11. Stratful, I.; Scrimshaw, M.; Lester, J. Conditions influencing the precipitation of magnesium ammonium phosphate. Water Res. 2001, 35, 4191-4199, doi:10.1016/S0043-1354(01)00143-9. 
12. Romero-Guiza, M.; Astals, S.; Mata-Alvarez, J.; Chimenos, J. Feasibility of coupling anaerobic digestion and struvite precipitation in the same reactor: Evaluation of different magnesium sources. Chem. Eng. J. 2015, 270, 542-549, doi:10.1016/j.cej.2015.02.057.

13. Munir, M.; Li, B.; Mardon, I.; Young, B.; Baroutian, S. Integrating wet oxidation and struvit precipitation for sewage sludge treatment and phosphorus recovery. J. Clean. Prod. 2019, 232, 1043-1052, doi:10.1016/j.jclepro.2019.06.007.

14. Yoshino, M.; Yao, M.; Tsuno, H.; Somiya, I. Removal and recovery of phosphate and ammonium as struvite from supernatant in anaerobic digestion. Water Sci. Technol. 2003, 48, 171-178, doi:10.2166/wst.2003.0045.

15. Chimenos, J.; Fernandez, A.; Villalba, G.; Segarra, M.; Urrutiocoechea, A.; Artaza, B.; Espiell, F. Removal of ammonium and phosphates from wastewater resulting from the process of cochineal extraction using MgO-containing by-product. Water Res. 2003, 37, 1601-1607, doi:10.1016/S0043-1354(02)00526-2.

16. Nelson, N.; Mikkelsen, R.; Hesterberg, D. Struvite precipitation in anaerobic swine lagoon liquid: Effect of $\mathrm{pH}$ and Mg:P ratio and determination of rate constant. Bioresour. Technol. 2003, 89, 229-236, doi:10.1016/S0960-8524(03)00076-2.

17. Pullammanappallil, P.; Mohan, G. Recovery of nutrients from water and wastewater by precipitation as struvite. US Patent, US20160185633A1. 30 June 2016.

18. Ruiz-Hermando, M.; Simyn, F.; Labanda, J.; Llorens, J. Effect of ultrasound, thermal and alkali treatments on the rheological profile and water distribution of waste activated sludge. Chem. Eng. J. 2014, 255, 14-22, doi:10.1016/j.cej.2014.06.036.

19. Liu, Y.; Li, X.; Kang, X. Short chain fatty acids accumulation and microbial community succession during ultrasonic-Pretreated sludge anaerobic fermentation process: Effect of alkaline adjustment. Int. Biodeterior. Biodegrad. J. 2014, 94, 128-133, doi:10.1016/j.ibiod.2014.07.004.

20. Tyagi, V.K.; Lo, S.; Appels, L.; Dewil, R. Ultrasonic Treatment of Waste Sludge: A Review on Mechanisms and Applications. Crit. Rev. Environ. Sci. Technol. 2014, 44, 1200-1288, doi:10.1080/10643389.2013.763587.

21. Kim, D.; Lee, J. Ultrasonic sludge disintegration for enhanced methane production. Bioprecess Biosyst. Eng. 2012, 35, 289-296, doi:10.1007/s00449-011-0588-x.

22. Deepanraj, B.; Sivasubramanian, V.; Jayaraj, S. Effect of substrate pretreatment on biogas production through anaerobic digestion offood waste. Int. J. Hydrogen Energy 2017, 42, 26522-26528, doi:10.1016/j.ijhydene.2017.06.178.

23. Uysal, A.; Yilmazel, Y.; Demirer, G. The determination of fertilizer quality of the formed struvite from effluentof a sewage sludge anaerobic digester. J. Hazard. Mater. 2010, 181, 248-254, doi:10.1016/j.jhazmat.2010.05.004.

24. Ometto, F.; Quiroga, G.; Pšenička, P.; Whitton, R.; Jefferson, B.; Villa, R. Impacts of microalgae pretreatments for improved anaerobic digestion: Thermal treatment, thermal hydrolysis, ultrasound and enzymatic hydrolysis. Water Res. 2014, 65, 350-361, doi:10.1016/j.watres.2014.07.040.

25. APHA. Standard Methods for Examination of Water and Wastewater, 18th ed.; American Public Health Association: Washington, DC, USA, 1992.

26. Ogunwande, G.; Osunade, J.; Adekalu, K.; Ogunjimi, L. Nitrogen loss in chicken litter compost as affected by carbon to nitrogen ratio and turning frequency. Bioresour. Technol. 2008, 99, 7495-7503, doi:10.1016/j.biortech.2008.02.020.

27. Watteau, F.; Geneviève, V. Characterization of organic matter microstructure dynamics during co-composting of sewage sludge, barks and green waste. Bioresour. Technol. 2011, 102, 9313-9317, doi:10.1016/j.biortech.2011.07.022.

28. Koster, I. Characteristics of the $\mathrm{pH}$-influenced adaptation of methanogenic sludge to ammonium toxicity. J. Chem. Technol. Biotechnol. 1986, 36, 445-455, doi:10.1002/jctb.280361003.

29. Le Corre, K.S.; Valsami-Jones, E.; Hobbs, P.; Parsons, S.A. Phosphorus Recovery from Wastewater by Struvite Crystallization: A Review, Crit. Rev. Environ. Sci. Technol. 2009, 39, 433-477, doi:10.1080/10643380701640573.

30. Battistoni, P.; De Angelos, A.; Pavan, P.; Prisciandaro, M.; Cecchi, F. Phosphorus removal from a real anaerobic supernatant by struvite crystallization. Water Res. 2001, 35, 2167-2178, doi:10.1016/S0043-1354(00)00498-X.

31. Pullmmanappallil, P.; Chynoweth, D.; Gerasimos, L.; Svoronos, S. Stable performance of anaerobic digestion in the presence of a high concentration of propionic acid. Bioresour. Technol. 2001, 78, 165-169, doi:10.1016/S0960-8524(00)00187-5.

32. Idelovitch, E.; Michail, M. Nitrogen removal by free ammonia stripping from high pH ponds. J. Water Pollut. Control Fed. 1981, 53, 1391-1401. Available online: https://www.jstor.org/stable/25041502 (accessed on 1 September 2020).

33. Kuba, T.; Smolders, G.; Van Loosdrecht, M.; Heijnen, J. Biological phosphorus removal from wastewater by anaerobic-anoxic sequencing batch reactor. Water Sci. Technol. 1993, 27, 241-252, doi:10.2166/wst.1993.0504.

34. Pinatha, Y.; Polprasert, C.; Englande, A.J., Jr. Product and cost perspectives of phosphorus recovery from human urine using solid waste ash and sea salt addition-A case of Thailand. Sci. Total Environ. 2020, 713, 136514, doi:10.1016/j.scitotenv.2020.136514.

35. Bougrier, C.; Carrere, H.; Delgenes, J. Solubilization of waste-activated sludge by ultrasonic treatment. Chem. Eng. J. 2005, 106, 163-169, doi:10.1016/j.cej.2004.11.013.

36. Salsabil, M.; Prorot, A.; Casellas, M.; Dagot, C. Pretreatment of activated sludge: Effect of sonication on aerobic and anaerobic digestibility. Chem. Eng. J. 2009, 148, 327-335, doi:10.1016/j.cej.2008.09.003.

37. Hidalgo, D.; Corona, F.; Martín-Marroquín, J.; del Álamo, J.; Aguado, A. Resource recovery from anaerobic digestate: Struvite crystallisation versus ammonia stripping. Desalination Water Treat. 2013, 57, 2626-2632, doi:10.1080/19443994.2014.1001794.

38. Jia, G.; Zhang, H.; Krampe, J.; Muster, T. Applying a chemical equilibrium model for optimizing struvite precipitation for ammonium recovery from anaerobic digester effluent. J. Clean. Prod. 2017, 147, 297-305, doi:10.1016/j.jclepro.2017.01.116. 
39. Lin, Q.; Chen, Z.; Liu, J.; Tang, B.; Ye, J.; Zhang, L. Optimization of struvite crystallization to recover nutrients from raw swine wastewater. Desalination Water Treat. 2015, 56, 3106-3112, doi:10.1080/19443994.2014.963686.

40. Divya, D.; Gopinath, L.R.; Christy, P. A review on current aspects and diverse prospects for enhancing biogas production in sustainable means. Renew. Sustain. Energy Rev. 2015, 42, 590-699, doi:10.1016/j.rser.2014.10.055.

41. Mao, C.; Zhang, T.; Wang, X.; Feng, Y.; Ren, G.; Tang, G. Process performance and methane production optimizing of anaerobic co-digestion of swine manure and corn straw. Sci. Rep. 2017, 7, 9379, doi:10.1038/s41598-017-09977-6.

42. Nutongkaew, T.; Prasertsan, P.; Sompong, O.; Chanthong, S.; Suyotha, W. Improved Methane Production Using Lignocellulolytic Enzymes from Trichoderma koningiopsis TM3 through Co-digestion of Palm Oil Mill Effluent and Oil Palm Trunk Residues. Waste Biomass Valorization 2020, 11, 5123-5136, doi:10.1007/s12649-019-00838-z.

43. Marti, N.; Pastor, L.; Bouzas, A.; Ferrer, J.; Seco, A. Phosphorus recovery by struvite crystallization in WWTPs: Influence of the sludge treatment line operation. Water Res. 2010, 44, 2371-2379, doi:10.1016/j.watres.2009.12.043.

44. Kataki, S.; West, H.; Clarke, M.; Baruah, D. Phosphorus recovery as struvite: Recent concerns for use of seed, alternative Mg source, nitrogen conservation and fertilizer potential. Resour. Conserv. Recycl. 2016, 107, 143-156, doi:10.1016/j.resconrec.2015.12.009. 